\title{
Social Responsibility of Public and Private Universities in Uganda
}

\author{
Livingstone Ddungu $^{1, *}$, Ritah N. Edopu ${ }^{2}$ \\ ${ }^{1}$ College of Education \& External Studies, Makerere University [ ${ }^{*}$ Corresponding author: \\ lddungu@yahoo.com], ${ }^{2}$ College of Engineering, Design, Art \& Technology, Makerere \\ University
}

\begin{abstract}
This paper presents a comparative analysis of corporate social responsibility (CSR) in public and private universities in Uganda. The paper is based on a cross-sectional survey that involved 780 respondents. These included 44 university administrators, 356 staff members and 380 students who were drawn from 22 universities. The findings show that both the public and private universities exhibited CSR albeit to a very low extent. Moreover, involvement in CSR differed significantly across the universities in such a way that it was much lower in public than in private universities. Drawing from the literature and university community partnership models of higher education delivery, a case for the universities' greater involvement with their communities is made after which recommendations towards realization of this goal are highlighted.
\end{abstract}

Keywords: CSR; University Community Partnerships; Engaged learning.

\section{$1 \quad$ Introduction}

The community engagement component of the university's traditional threetrack mandate disposes universities towards in Corporate Social Responsibility (CSR) activities (Schneller \& Thöni, 2011; Adomssent \& Michelsen, 2006). Indeed, the institutions' teaching role produces graduates who benefit society by acting as skilled change agents; through their research role, they generate knowledge and innovations that enhance societal technological and scientific advancement; and their community service role is a form of engagement with and outreach to the outside community (Weiss, 2016). When CSR is perceived this way, it is evident that all universities exhibit it incontrovertibly (Dima \& 
Resch, 2016; McDonald \& Liebenberg, 2006). Universities in Uganda are not an exception.

Uganda's universities produce over 400,000 graduates per annum and their supply in this very case is much greater than the absorptive capacity of the country's economy (Kayinza, 2015; Pletscher, 2015). Their research output has contributed knowledge and innovations for different industries in Uganda, including agriculture (e.g. coronal coffee), food and nutrition (e.g. banana flour), health (e.g. medicines for treating tropical diseases), construction (e.g. lighter yet stronger and material-saving bricks), motor vehicle assembling and engineering (e.g. electric car), and robotics amongst others (Kayongo, 2015; Musiige, 2014; Mulupi, 2014; Kavuma, 2011). According to Ddungu (2015), these institutions have also engaged with their communities through programmes and activities in which their staff members and students teach and learn, respectively, in interaction with the outside community members who may be individuals, groups or institutions and operating either at local, national, regional or international level. From the traditional perspective, there is absolutely nothing wrong with regarding these outputs and activities as expressions of universities' CSR. In fact, it is this type of CSR that qualifies Ugandan universities for government funding (Nkundabanyanga \& Okwee, 2011). This is however, not the kind of CSR investigated in this paper.

The CSR on which this paper focuses is the type defined from a generic perspective that applies to all organisations, irrespective of the type of business they do and the industry or sector to which they belong. This type of CSR is defined as any organisation's concern for its own survival, for the community it serves and for the environment in which it operates (Katamba et al., 2014, 2012; Turyakira et al., 2012; Albareda et al., 2006). In this context, CSR is not a requirement or even a role; it is regarded as a form of 'concern for others' expressed as a responsibility to do business right, judiciously while exercising generosity that does not hurt it (Katamba \& Nkiko, 2016). Surely, universities can also exhibit this type of CSR as they play their traditional roles (Nasongkhla \& Donaldson, 2015). Generally, an organisation exhibits concern for itself by ensuring its economic survival and sustainability; it exhibits concern for community by operating legally (by following its industry regulations), ethically (by doing the right thing or observing the set ethical standards), philanthropically (by giving back to and/or creating opportunities that benefit the community it serves), and by showing concern for environment in which it operates (by being sensitive enough not to damage it) (Mansour et al., 2015; Rochlin et al., 2015; González \& Martinez, 2004).

Exhibiting CSR in a generic sense has always been a part of the African culture, but many enterprises first derided it as a joke, a cost and an oxymoron in investment parlance (Katamba \& Nkiko, 2016; Lee, 2007). Few universities in Europe and America practiced it mainly through granting scholarships to 
excellent but economically disadvantaged students, giving back to community through sharing research findings and innovations, donating to younger universities, promoting human rights, applying fair operating practices, and being sensitive to the environment (Dima \& Resch, 2016; Leitao \& Silva, 2007). These universities included Harvard University, University of Cambridge, Yale University, University College of London, Imperial College of London, University of Oxford, University of Chicago, Princeton University, Massachusetts Institute of Technology, and California Institute of Technology (Nejati et al., 2011). It was not until the late 1990s that CSR became almost globally sanctioned and promoted as a best business practice that universities and other organisations that wanted to operate in a sustainable manner needed to integrate in their strategic plans and day-to-day activities (Alzyoud \& BaniHani, 2015; Asemah et al., 2013).

CSR started to be embraced as a strategic goal after realising that exhibiting it was a social marketing strategy that could enable enterprises to effectively make themselves appealing to and therefore willingly supported by the communities they serve, and that this strategy would promote them in the market while also creating opportunities for them to attract more clients, increase their market share and qualify for tax exemptions granted when an entity engages in charitable work (Rochlin et al., 2015; Palmer, 2012; Mugisa, 2011). Universities could no longer afford to ignore this strategy. As public funding dwindled, they needed to undergo a paradigm shift to become more corporatized and find ways of strengthening their relationship with industry and of increasing their competitiveness and appeal to donors and students who now became their main source of financing (Shawyun et al., 2012; Miller, 2011). Different universities have since the 1990 s been embracing this strategy. However, not much research has been conducted to establish the extent to which those in Uganda have exhibited its adoption.

The few studies that have been conducted about CSR in universities in Uganda include that of Kayongo (2014). This study however, investigated awareness and application CSR as a dimension of the Triple Bottom Line and it dealt with only private universities, thereby leaving the case for public universities uncovered. Amina and Turyahebwa's (2015) study covered the participation of some universities in Uganda in community service, but its focus was on this participation as a university role, not as an aspect of CSR. This was also the case with a study conducted by Ddungu (2014). Despite having covered some aspects that universities can use to promote their genetic CSR, Ddungu (2014) approached all the aspects as defining attributes of individual lecturers' participation in community service and how this participation predicted by the dons' evaluation. Therefore, not much as has been covered about how universities in Uganda exhibit CSR in a generic sense and whether this exhibition differs between public and private universities. Accordingly, the 
specific objective of this paper is to analyse the extent to which these universities exhibit CSR and whether this extent differs between public and private universities in Uganda.

\section{$2 \quad$ Literature Review}

\subsection{Theoretical Review}

Three theories have so far been developed to explain CSR and how organisations such as universities can follow them to execute their own social responsibilities. These are the corporate social responsibility theory, the triple bottom line model and the stakeholder theory (Brusseau, 2015; Rashid, 2015; Wicks et al., 2004). This paper is however, guided by the Corporate Social Responsibility Theory (CSRT). This theory assumes that every organisation operates in interaction with the surrounding community and the larger world. Therefore, the responsibility of any organisation has is made up of four dimensions. The first is the economic dimension which focuses on the duty to make money. This dimension provides a business version of an organisation and stresses the duty that every organisation for survival (Brusseau, 2015). CSRT states that in this dimension, the organisation strives to raise the economic resources it needs to survive (Carroll \& Shabana, 2010). The responsibility requires the organisation to raise and use economic resources to make profits or surplus it needs to grow unceasingly; an organisation that fails to execute this responsibility effectively is doomed to perish (Carroll \& Shabana, 2010). For non-profits such as universities, this obligation is executed using public financing, donations, grants and internal income generating activities such as commercial research, tuition and other fees (Brusseau, 2015; Lee, 2007).

The other is the legal dimension, which is an organisation's duty to strictly observe the rules and regulations that govern its internal operations as well as the industry in which it conducts its business (Lindgreen et al., 2008). This dimension regards observance of the governing rules and regulations as a proactive duty, but not as something an organisation can decide to follow or not at its discretion (Garriga \& Melé, 2004). The organisation has to accept the regulations in good faith and make all efforts to obey them to their letter and spirit so as to operate in manner that benefits not only itself alone but also society as a whole. The third is the ethical dimension, which focuses on an organisation's duty to do what's right even when this is not required by the law (Omran, 2015; Crane \& Matten, 2007). An organisation succeeds at implementing this duty by viewing itself and operating as living citizen that 
provides a service that benefits, but not damages society. In a specific sense, this responsibility is exercised by setting and following ethical standards that promote doing the right thing for the good of the organisation, its members, those it serves and society at large (Toukabri et al., 2015; Crane \& Matten, 2007). The fourth and last dimension recognised by CSRT is philanthropy. This dimension requires organisations to give back to the community they serve as a way of contributing to improving its welfare as a whole or in terms of its individual members (Brusseau, 2015; Toukabri et al., 2015).

Generally, CSRT suggests that an organisation exhibits generic CSR by functioning as a citizen that sustains itself not only by raising the economic resources it requires to facilitate its business and growth but also by doing so and conducting its business operations in a manner that serves society in a legal, ethical and philanthropic way. This paper investigates how universities in Uganda exhibit this kind of CSR.

\subsection{Universities' Exhibition of CSR}

The available literature indicates that universities exhibit CSR in different ways. One of these dimensions is the legal component, which universities implement by following the teaching, research and instructional infrastructural guidelines, standards and regulations set by their National Council for Higher Education (NCHE) (Dahlsrud, 2008). These guidelines, standards and regulations, generally referred to as quality assurance standards, include having the required quality of academic staff, required staff-student ratio, all offered academic programmes duly approved by the NCHE, and having all requirements for lecture space and furniture, library space, materials and furniture, and laboratory space, apparatus and chemicals fulfilled according to the NCHE set standards (Brusoni et al., 2014; Burke \& Marshall, 2010; Eaton, 2010; Hayward, 2006). A university that exhibits legal CSR strives to plan for and observe all these guidelines, fulfil the standards and abide by the regulations deemed necessary for it to provide the quality of education students need to graduate into productive citizens (Dima et al., 2013; Eaton, 2012).

According to Dahan and Senol (2012), the legal dimension of CSR is also exhibited by observing quality assurance standards that promote provision of quality instruction, research and innovation, appropriate health and safety for university members, and apt intellectual property management. It is irresponsible of any university that attempts to avoid, compromise or violate their NCHE's set standards, guidelines and regulations, since, in so doing, the university falls short of playing its traditional roles of teaching, research and community service effectively, efficiently and to the satisfaction of its service students, employers and society at large (Manock et al., 2013). 
The economic dimension of CSR is exhibited by universities by raising required economic resources not in an exploitative manner, but by using a fees and tuition structure that is fair to most students or their sponsors given the economic conditions in their country (Reiser, 2007). Proper implementation of this responsibility involves university management ensuring that any increments in its funding policy do not just maximise net realisable surplus but that they are justifiable from the perspective of improving the quality of provided education, and that all raised funds are transparently and credibly utilised (Chen, 2015; Ahmad, 2012). It is noted that while these observations explain how universities exhibit the legal and economic dimension of CSR, they do so using universities outside Uganda. This leaves the extent to which universities in Uganda play demonstrate these responsibilities still questionable.

Research further reveals that universities demonstrate the ethical dimension of CSR by setting and following ethical standards that promote doing the right thing for their own good and for the good of their members (staff members and students), and those they serve (employers and society at large) (Dahan \& Senol, 2012). This effectively boils down to doing what is publicly and managerially regarded as right and avoiding what is publicly and managerially considered wrong (The Council for Industry and Higher Education, 2009). Doing what is right involves university management fulfilling their promises to their employees and students, providing the quality of education that enable students to develop their talents optimally, equip relevant skills and knowledge, and ensuring that students realise value for the money they pay in tuition and other fees (Nasongkhla \& Donaldson, 2015; Ahmad, 2012). It also involves lecturers teaching, supervising and evaluating students as scheduled and professionally, conducting their non-teaching duties such as administrative and research activities as expected, and also non-academic staff members performing their jobs efficiently and effectively (Dima et al., 2013). Universities also play ethical by imparting morally acceptable behaviour in their students (Esfijani et al., 2012).

The other dimension of CSR involves a university participating in philanthropy by granting scholarships to students who qualify for university education and those who are talented, but are economically disadvantaged, giving back to community by freely organising community seminars for sharing research findings and innovations that community members can use to improve their welfare, donating to relatively younger universities, organising community sensitisation forums for promoting observance of human rights, and encouraging fair operating practices such as sponsoring staff members for further studies, including PhDs (Dima \& Resch, 2016; Katamba \& Nkiko, 2016; Leitao \& Silva, 2007; Vest, 2006). Universities also play philanthropic by allowing these communities to use their recreational grounds, opening up for free primary and secondary school student visits and inspirational tours, 
exhibiting other public acts of generosity such as encouraging students to give something such as positive experiences to the less fortunate members back to their communities (Dima \& Resch, 2016; Alzyoud \& Bani-Hani, 2015; Asemah et al., 2013; Leitao \& Silva, 2007). These institutions also exhibit philanthropy by opening up to their surrounding communities to allow their members to sell goods and services to students and employees (Campbell, 2014). This form of philanthropy creates market for the community, thereby promoting employment opportunities to members of their surrounding communities.

Universities further give back to community through what is increasingly referred to as civic engagement with community involving initiating community service projects such as those which give humanitarian aid to people hit by natural disasters such as hunger, floods, wild fire, and other catastrophes (Manock et al., 2013; Miller, 2011). These institutions also encourage their students to actively engage in curricular activities that increase their learning interaction with communities, thereby increasing students' awareness of the social needs and problems of their communities, teach them grant-writing and grant-making skills, and encourage them to invest in nonprofit initiatives such as starting clubs that contribute funds for the needy (Olberding, 2012; Irvin, 2005).

Generally, the cited literature indicates that universities exhibit CSR in different ways classified in four main dimensions, which include the legal, economic, ethical and philanthropic dimensions. The literature is however, cited based on universities outside Uganda. Not much research has been conducted in this area as far as universities in Uganda are concerned. This effectively suggests that the available literature is still devoid of how these universities exhibit CSR in each of these dimensions. This study was conducted to fill this gap.

\section{Research Methods}

The study followed a cross-sectional comparative survey design. Table 1 shows the population and sample.

Table 1: Population and Sample

\begin{tabular}{lllll}
\hline Unit & Population* & Sample** & Actual sample & Response rate (\%) \\
\hline Universities & 39 & 36 & 22 & 61.1 \\
Administrators & 78 & 66 & 44 & 66.7 \\
Staff & 10676 & 375 & 356 & 94.9 \\
Students & 140687 & 384 & 380 & 99.0 \\
\hline * Culled from NCHE (2015) and Uganda Bureau of Statistics (2015). \\
** Based on Krejcie \& Morgan's sample size estimation table.
\end{tabular}


Table 1 indicates that Uganda had a total of 39 universities at the time when the study was conducted. Thirsty six of them were selected as per Krejcie \&Morgan's (1970) Sample Determination Table. They were selected using stratified and proportional simple random sampling. Stratified sampling was use to divide the list of all universities in Uganda into two lists. One of the lists was for private universities and the other was for public categories. Proportional simple random sampling was then used to select individual universities from each list. This was intended to not only give each university in each list an equal chance of participating in the study but also to select a proportional number of universities from each list. The list of public universities had seven universities four (57.1\%) of which were selected. The list of private universities had 32 universities 18 (56.2\%) of which were selected. Therefore, a total of $22(61.1 \%)$ universities were selected. All the universities were selected in central and eastern Uganda.

University administrators, staff members and students were selected to provide data which was required to establish how their respective universities exhibited CSR at the respondents' respective levels. All respondents were selected using convenience sampling because this sampling technique facilitates respondent selection according to their availability, accessibility and willingness to participate in a study (Amin, 2005). The selected university administrators included Vice Chancellor (VCs) and University Secretaries (USs), since these are the officers whose official duties include sanctioning a university's effort to promote CSR. Since each university has one VC and one US, the 39 universities were expected to have 78 of these officials. Both academic and non-academic staff members were selected, since they each were in a position to tell their perspective of how CSR was exhibited in their universities.

Data were collected using self-administered questionnaires, since, by virtue of their occupations, all the respondents were literate enough to read the questionnaire items and respond to them in writing. Before their administration, the questionnaires were tested for validity using the Content Validity Method and for reliability using the Cronbach Alpha method of internal consistency. The validity indices for the administrator, staff and student questionnaire were $.911, .905$ and .922 , respectively. Their Cronbach Alpha coefficients were .866, .876 and .899 , respectively. These validity and reliability coefficients were all greater than the 0.7, the minimum acceptable threshold (Amin, 2005). Therefore, the questionnaires were valid and reliable enough to collect accurate and dependable data. The data were analysed using data transformation, the mean comparison with independent $\mathrm{T}$-samples. The arithmetic technique of the data transformation method was applied to develop the global view of how all respondents perceived exhibition of CSR in their universities categorised as public and private universities. The mean comparison technique was used to 
determine the perception on average and the independent $\mathrm{T}$-samples test was used to establish the difference in the perception. The analysis was aided by the SPSS program (Version 22).

\section{$4 \quad$ Findings and Discussion}

The objective of this study was to establish the extent to which these universities exhibited CSR and whether this extent differs between public and private universities in Uganda. This objective was met by asking respondents to use a 5-point Likert scale of responses ranging from Strongly Disagree (1) through Disagree (2), Somewhat Agree (3) and Agree (4) to Strongly Agree (5) to indicate the extent to which they agreed or disagreed with their universities' exhibition of CSR in terms of its specific indicators that applied at their level. Findings are presented in Table 2. 
Table 2: Mean scores on Attributes of CSR

Attribute

Min Max Public Private

$\mathrm{t}$

Legal

The university's faculty meet the quality standards in terms of qualifications required by NCHE

The lecture rooms available in the university meet the space and furniture standards set by NCHE

The library facilities available to the university meet the quality assurance requirements set by NCHE

The university's laboratory facilities, if any, meet the quality standards set by NCHE

The university's lecturer-student ratio is as required by NCHE

All offered academic programmes duly approved by the NCHE

Regulations set by the NCHE to guide research are strictly observed by the university

NCHE standards for intellectual property management are strictly observed at the university

The university's health and safety conditions meet the standards required by NCHE

\section{Economic}

The university's fees structure is fair when compared to the income backgrounds of most students

The increments the university's management makes in the fees policy are justifiable

The money raised by the university is utilized transparently in a credible manner.

Ethical

Ethical standards set by the NCHE for research and innovation are strictly observed by the university.

The academic programmes offered enable students to develop their talents to their expectations.

The academic programmes offered enable students to develop skills required in the job market

The university management fulfils the promises it makes to staff members.

The university management fulfils the promises it makes to students.

The university students realise value for the money they pay in tuition and other fees

The university's lecturers teach scheduled lectures professionally

\begin{tabular}{|c|c|c|c|c|}
\hline 5 & 4.36 & 2.56 & 8.990 & .000 \\
\hline 5 & 2.16 & 3.88 & 23.988 & .000 \\
\hline 5 & 2.14 & 3.74 & 18.456 & .000 \\
\hline 5 & 3.64 & 3.90 & 9.677 & .000 \\
\hline 5 & 2.26 & 3.76 & 40.445 & .000 \\
\hline 5 & 4.66 & 3.64 & 22.223 & .000 \\
\hline 5 & 4.34 & 3.52 & 7.932 & .000 \\
\hline 5 & 4.16 & 3.52 & 9.867 & .000 \\
\hline 5 & 4.45 & 3.75 & 7.099 & .000 \\
\hline 5 & 4.33 & 3.71 & 8.765 & .000 \\
\hline 5 & 1.12 & 2.42 & 13.876 & .000 \\
\hline 5 & 1.05 & 2.35 & 14.456 & .000 \\
\hline 5 & 4.35 & 3.57 & 6.981 & .000 \\
\hline 5 & 1.52 & 2.02 & 50.911 & .000 \\
\hline 5 & 1.89 & 3.96 & 69.544 & .000 \\
\hline 5 & 1.57 & 1.99 & 7.329 & .000 \\
\hline 5 & 1.62 & 1.97 & 11.009 & .000 \\
\hline 5 & 2.29 & 3.59 & 13.133 & .000 \\
\hline 5 & 2.44 & 3.64 & 15.109 & .000 \\
\hline
\end{tabular}




\begin{tabular}{|c|c|c|c|c|c|c|}
\hline Attribute & Min & Max & Public & Private & $\mathrm{t}$ & Sig. \\
\hline The university's lecturers supervise students' research professionally & 1 & 5 & 2.04 & 3.74 & 22.092 & .000 \\
\hline The university's lecturers evaluate students professionally, awarding marks justifiably & 1 & 5 & 2.21 & 3.21 & 12.678 & .000 \\
\hline The university's lectures conduct their non-teaching duties as scheduled & 1 & 5 & 3.57 & 4.37 & 16.786 & .000 \\
\hline The university's non-teaching staff conduct their duties as scheduled & 1 & 5 & 3.71 & 4.31 & 11.098 & .000 \\
\hline The university imparts morally acceptable behaviour to its students & 1 & 5 & 1.97 & 4.37 & 42.312 & .000 \\
\hline \multicolumn{7}{|l|}{ Philanthropic } \\
\hline The university grants scholarships to students who qualify but are economically disadvantaged & 1 & 5 & 2.40 & 1.20 & 12.888 & .000 \\
\hline The university grants scholarships to talented but needy students & 1 & 5 & 1.27 & 1.23 & 6.876 & .000 \\
\hline The university sponsors community seminars to share research findings and innovations & 1 & 5 & 2.44 & 1.83 & 10.854 & .000 \\
\hline The university donates to other institutions that are in need & 1 & 5 & 1.63 & 2.30 & 8.976 & .000 \\
\hline The university sponsors community sensitisation forums for promoting observance of human rights & 1 & 5 & 1.91 & 2.22 & 8.094 & .000 \\
\hline The university sponsors its staff members for further training, including PhDs & 1 & 5 & 3.65 & 2.35 & 33.376 & .000 \\
\hline The university allows the surrounding community to use its recreational grounds free of charge & 1 & 5 & 4.08 & 3.69 & 9.986 & .000 \\
\hline The university is open to free primary and secondary school student visits and inspirational tours. & 1 & 5 & 4.11 & 3.79 & 8.066 & .000 \\
\hline The university has programme for sending students to share positive experiences with the community & 1 & 5 & 1.17 & 2.37 & 7.773 & .000 \\
\hline University allows members of the surrounding community to transact with its staff and students & 1 & 5 & 1.20 & 2.43 & 6.550 & .000 \\
\hline The university has projects by which it gives humanitarian aid to people hit by disasters & 1 & 5 & 1.10 & 2.34 & 8.287 & .000 \\
\hline University encourages student activities that enable students to interact with outside communities & 1 & 5 & 2.09 & 2.43 & 6.789 & .000 \\
\hline The university encourages students to start clubs that contribute funds for the needy & 1 & 5 & 1.09 & 2.08 & 6.087 & .000 \\
\hline Overall CSR Exhibition & 1 & 5 & 2.56 & 3.02 & 16.199 & .000 \\
\hline
\end{tabular}


From Table 2, the mean values that are close to ' 2 ' and ' 1 ' imply that respondents disagreed and strongly disagreed, respectively, and in either case, they revealed a perception that their universities did not exhibit any CSR defined by the corresponding indicators. The mean values close to ' 3 ' imply that respondents somewhat agreed, thereby expressing a perception that the extent to which their universities exhibited the corresponding CSR indicators was very low. The mean values close to ' 4 ' indicate that universities' extent of exhibiting the corresponding CSR indicators was moderate. Any mean values that were close to ' 5 ' indicate a perception that the extent of the universities' exhibition of CSR was high. The minimum and maximum values indicate that respondents' perception of this extent ranged between strongly disagree $(\mathrm{Min}=$ $1)$ and strongly agree $(\operatorname{Max}=5)$. This suggests that there were respondents who felt that their universities did not exhibit any CSR and those who felt that their universities' extent of exhibiting this responsibility was high. The mean values corresponding to the overall CSR exhibition indicate however, that on average, the universities exhibited this responsibility to a very low extent, irrespective of whether they were public $($ Mean $=2.56)$ or private $($ Mean $=3.02)$. This implies that the universities executed CSR at very suboptimal levels.

The corresponding computed level of significance was less than the conventional .01 level of significance, implying that the corresponding $\mathrm{T}$-value was significant $(\mathrm{T}=16.199$, Sig. $=.000<.01)$. This reveals that despite exhibiting very low CSR, there was a significant difference in the extent to which this responsibility was exhibited by public and private universities. The magnitudes of the mean values indicate that the value corresponding to private universities was relatively larger than that corresponding to public universities. This suggests that the difference was such that on the whole, CSR exhibited by public universities was much lower than that displayed by private universities. The analysis of the mean values corresponding to the specific CSR indicators reveals that private universities exhibited better legal CSR by realising a relatively better lecturer-student ratio $($ Mean $=3.76)$ compared to public universities (Mean $=2.26)$.

The findings also suggest that private universities exhibited ethical CSR more than public universities. In particular, private universities offered academic programmes that moderately enabled students to develop skills required in the job market, but public universities did not (Mean $=3.96$ for private universities compared to Mean $=1.89$ for public universities). Private universities enabled their students to realise value for the money which they paid in tuition and other fees (Mean $=3.59$ for private universities compared to Mean $=2.29$ for public universities). Furthermore, private universities' dons taught the scheduled lectures more professionally and without dodging any, except in cases when they were constrained by justifiable causes (Mean $=3.64$ for private universities compared to mean $=2.44$ for public universities). 
Private university lecturers also supervised students' research more professionally and without turning down appointments, except in cases when they were constrained by justifiable causes (Mean $=3.74$ for private universities compared to mean $=2.04$ for public universities). Their lecturers also evaluated their students and awarded marks more professionally than their counterparts in public universities (Mean $=3.21$ for private universities compared to mean $=2.21$ for public universities). Similarly, private universities demonstrated more ethical CSR in terms of ensuring that their teaching and non-teaching staff members conducted their duties as scheduled and in terms of imparting morally acceptable behaviour to their students.

Notwithstanding the fact that private universities demonstrated more ethical CSR compared to public universities, the reverse happened as far as most dimensions of the legal form of CSR was concerned. in particular, public universities exhibited better CSR in terms of offering academic programmes dully approved by the UNCHE (Mean $=4.66$ for public universities compared to Mean $=3.64$ for private universities). Public universities were also better at observing regulations set by the UNCHE to guide research (Mean $=4.34$ for public universities compared to Mean $=3.52$ for private universities) and at ensuring that UNCHE standards for intellectual property management were strictly observed (Mean $=4.16$ for public universities compared to Mean $=3.52$ for private universities). Furthermore, public universities were better at meeting the health and safety standards required by UNCHE (Mean $=4.45$ for public universities compared to Mean $=3.75$ for private universities.

Furthermore, the analysis of the mean values corresponding to the philanthropic dimension of CSR indicate that notwithstanding the significant difference reported in the extent to which public and private universities exhibited this dimension, both categories of the universities did not implement most of its indicators. The magnitudes of the mean values reveal that the only indicators that these universities exhibited this dimension and which public universities performed moderately and relatively better than private universities included sponsoring staff members for further training, including $\mathrm{PhDs}$, which private universities did not do (Mean for public universities $=3.65$ compared to Mean $=2.35$ for private universities), allowing community members to use their recreational grounds free of charge (Mean $=4.08$ for public universities compared to Mean $=3.69$ for private universities), and being open to free primary and secondary school student visits and inspirational tours (Mean = 4.11 for public universities compared to Mean $=3.79$ for private universities).

The findings indicate that generally, both public and private universities in Uganda exhibit CSR to a very low extent, which points to the need for these universities to improve their execution of this responsibility. In specific terms, public universities are worse than private universities when it comes to exhibiting ethical and economic CSR. The reverse occurs when it comes of 
demonstration of legal CSR and philanthropy. Most of the philanthropic CSR is not exhibited by both categories of universities, but this study has not identified the cause of this situation.

The management of both public and private universities should improve implementation of CSR. Management in private universities should focus more on improving legal CSR but without neglecting other dimensions. The management in public universities should emphasise implementation of economic and ethical CSR without ignoring other dimensions. Both categories of universities should enhance their philanthropic efforts.

\section{References}

Adomssent, M., \& Michelsen, G. (2006). German academia heading for sustainability? Reflections on policy and practice in teaching, research and institutional innovations. Environmental Education Research, 12(1), 85-99.

Ahmad, J. (2012). Can a university act as a corporate social responsibility (CSR) driver? An analysis. Social Responsibility Journal, 8(1), 77-86.

Albareda, L., Ysa, T., Lozano, J. M., \& Roscher, H. (2006). The role of governments in fostering CSR. In Corporate Social Responsibility (pp. 112128). London: Palgrave Macmillan.

Alzyoud, S. A., \& Bani-Hani, K. (2015). Social responsibility in higher education institutions: Application case from the Middle East. European Scientific Journal, 11(8), 201-217.

Amin, M. (2005). Social science research: Conception, methodology and analysis. Kampala: Makerere University Printery.

Amina, N., \& Turyahebwa, A. (2015). Institutional efficiency in selected universities in Uganda. Journal of Education and Practice, 6(10), 90-96.

Asemah, E. S., Okpanachi, R. A., \& Olumuji, E. P. (2013). Universities and corporate social responsibility performance: An implosion of the reality. African Research Review, 7(4), 195-224.

Brusoni, M., Damian, R., Sauri, J. G., Jackson, S., Kömürcügil, H., Malmedy, M., \& Rostlund, A. (2014). The concept of excellence in higher education. Occasional Paper, 20.

Brusseau, J. (2015). The business ethics workshop: Three theories of corporate social responsibility. Available from: http://catalog.flatworldknowledge.com/bookhub/1695?e=brusseau-ch13_s02 [Accessed 10 December 2016].

Burke, L. M., \& Marshall, J. A. (2010). Why national standards won't fix American education: Misalignment of power and incentives. Backgrounder. No. 2413. Heritage Foundation. 
Campbell, D. A. (2014). Practicing philanthropy in American higher education: Cultivating engaged citizens and non-profit sector professionals. Journal of Public Affairs Education, 217-231.

Carroll, A. B., \& Shabana, K. M. (2010). The business case for corporate social responsibility: A review of concepts, research and practice. International journal of management reviews, 12 (1), 85-105.

Chen, S. H. (2015). A strategic planning model for developing open educational resources. Chulalongkorn University: $\mathrm{PhD}$ Dissertation.

Crane, A., \& Matten, D. (2007). Business ethics ( $2^{\text {nd }}$ Ed.). New York: Oxford University Press Inc.

Dahan, G. S., \& Senol, I. (2012). Corporate social responsibility in higher education institutions: Istanbul Bilgi University case. American International Journal of Contemporary Research, 2(3), 95-103.

Dahlsrud, A. (2008). How corporate social responsibility is defined: an analysis of 37 definitions. Corporate social responsibility and environmental management, 15(1), 1-13.

Ddungu, L. (2014). Evaluation as a predictor of academic staff participation in community service in universities in Uganda. [Forthcoming Journal Article].

Dima, A. M., Vasilache, S., Ghinea, V., \& Agoston, S. (2013). A model of academic social responsibility. Review of Administrative Sciences, 23-43.

Eaton, J. S. (2010). Accreditation and the federal future of higher education. Academe, 96(5), 21-30.

Eaton, J. S. (2012). Planning for higher education: The future of accreditation. Academe, 40(5), 1-8.

Esfijani, A., Hussain, F. K., \& Chang, E. (2012). An approach to university social responsibility ontology development through text analyses. Paper presented at the IEEE 5th International Conference on Human System Interactions, IEEE-HSI-2012.

Garriga, E., \& Melé, D. (2004). Corporate social responsibility theories: Mapping the territory. Journal of business ethics, 53(1-2), 51-71.

González, M. D. L. C., \& Martinez, C. V. (2004). Fostering corporate social responsibility through public initiative: From the EU to the Spanish case. Journal of Business Ethics, 55(3), 275-293.

Hayward, F. M. (2006). Quality assurance and accreditation of higher education in Africa. A paper presented at the Conference on Higher Education Reform in Francophone Africa: Understanding the Keys of Success held at Ouagadougou, June 13-15.

Irvin, R. A. (2005). The student philanthropists: Fostering civic engagement through grant making. Journal of Public Affairs Education, 11(4), 325-336.

Katamba, D., \& Nkiko, C. M. (2016). The Landscape of Corporate Social Responsibility in Uganda: Its Past, Present and Future. In Corporate Social 
Responsibility in Sub-Saharan Africa (pp. 153-171). Springer International Publishing.

Katamba, D., Nkiko, C. M, Tushabomwe-Kazooba, C., Babiiha Mpisi, S., Kemeza, I., \& MJ Wickert, C. (2014). Integrating corporate social responsibility into efforts to realize millennium development goals: Lessons from Uganda. World Journal of Entrepreneurship, Management and Sustainable Development, 10(4), 314-333.

Katamba, D., Tushabomwe-Kazooba, C., Babiiha Mpisi, S., Nkiko, C. M., Nabatanzi-Muyimba, A. K., \& Hensley Kekaramu, J. (2012). Corporate social responsibility management in Uganda: Lessons, challenges, and policy implications. International Journal of Social Economics, 39(6), 375-390.

Kavuma, R. M. (2011). Uganda's first electric car proves the potential of Africa's universities. Available from: https://www.theguardian.com/globaldevelopment/poverty-matters/2011/nov/10/uganda-electric-car-education [Accessed 12 December 2016].

Kayinza, M. (2015). Youth unemployment in Uganda. Available from: http://ofcourse.oru.se/ waf-e/maukah141/?p=71 [Accessed 10 December 2016]

Kayongo, P. (2015). Investing in research and innovation as a key to productive university education in Uganda. Ndejje University: Unpublished Manuscript.

Kayongo, P. M. (2014). Levels of awareness and application of the triple bottom line in private universities in central Uganda. Ndejje University Magazine, 5, 57-66.

Krejcie, R.V., \& Morgan, D.W. (1970). Determining sample size for research activities.

from:

https://www.google.com/\#q=Kreacje+and+Morgan+Sample+Determination +table\&spell $=1$ [Accessed 1 December 2016].

Lee, M. P. (2007). A review of the theories of corporate social responsibility: Its evolutionary path and the road ahead. International Journal of Management Reviews, 10(1), 53-73

Leitao, J., \& Silva, M. J. (2007). CSR and social marketing: What is the desired role for universities in fostering public policies? University of Beira Interior: Unpublished MBA Thesis.

Lindgreen, A., Swaen, V., \& Johnston, W. (2008). Corporate social responsibility: an empirical investigation of US organizations. Journal of Business Ethics, 46 (3), 23-29.

Manock, I., Islam, R., Hicks, J., Sappey, R. B., \& Ingham, V. (2013). Perceptions of institutional and social response to frequent flooding in an Australian rural town. Australian Journal of Emergency Management, 28 (1), 42-48. 
Mansour, S., Owayid, A. M., \& Ramadan, M. (2015). The impact of corporate social responsibility on the firm's financial performance: The case of publicly listed companies in the United Arab Emirates. In International Conference on Knowledge Management in Organizations (pp. 209-220). Springer International Publishing. Available from: http://link.springer.com/chapter/10.1007/978-3-319-21009-4_16 [Accessed 10 December 2016]

McDonald, F., \& Liebenberg, J. (2006). The perceptions of employees in a private higher education institution towards corporate social responsibility. South African Journal of Human Resource Management, 4(1), 27-35.

Miller, V. A. (2011). Engaging students in student philanthropy programs to impact future giving: A Multi-case study of three public research institutions. University of Georgia: PhD Dissertation in Education.

Olberding, J. C. \& Millisor, J. (2009). Student philanthropy in colleges and universities. Academic Exchange Quarterly, 13(4), 11-16.

Mugisa, J. (2011). The effects of corporate social responsibility on business operations and performance: Case study-Vision Group and Uganda Clays Limited. Uganda Martyrs University: PhD Dissertation.

Mulupi, D. (2014). Introducing the 'made in Uganda' electric car. Available from: http://www.howwemadeitinafrica.com/introducing-the-made-inuganda-electric-car/ [Accessed 12 December 2016].

Musiige, G. (2014). Research at Makerere University: Faculty perceptions towards the factors that influence research productivity. University of Oslo: Master of philosophy in Higher Education

Nasongkhla, J., \& Donaldson, J. A. (2015). University social responsibility (USR): Identifying an ethical foundation within higher education institutions. The Turkish Online Journal of Educational Technology, 14(4), 165-172.

Nejati, M., Shafaei, A., Salamzadeh, Y., \& Daraei, M. (2011). Corporate social responsibility and universities: A study of top 10 world universities' websites. African Journal of Business Management, 5(2), 440-447.

Nkundabanyanga, S. K., \& Okwee, A. (2011). Institutionalizing corporate social responsibility (CSR) in Uganda: Does it matter? Social Responsibility Journal, 7(4), 665-680.

Olberding, J. C. (2012). Does student philanthropy work? A study of long-term effects of the learning by giving approach. Innovative Higher Education, 37(2), 71-87.

Omran, M. A. (2015). Theoretical perspectives on corporate social responsibility disclosure: A critical review. International Journal of Accounting and Financial Reporting, 5(2), 38-55

Palmer, H. J. (2012). Corporate social responsibility and financial performance: Does it pay to be good? CMC Senior Theses. Paper 529. 
Available from: http://scholarship.claremont.edu/cmc_theses/529 [Accessed 10 December 2016

Pletscher, M. (2015). Youth unemployment in Uganda: Roots of the problem and possible ways to mitigate them. University of St. Gallen: Master in International Affairs and Governance

Rashid, A. (2015). The influence of stakeholder power on corporate social responsibility: Evidence from a relationship-based economy. Social Responsibility Journal, 11(2), 270 - 289.

Reiser, J. (2007). Managing university social responsibility. International sustainable campus network: Best practices - Future challenges. Available from: http://www.international-sustainable-campusnetwork.org/viewdocument/108-panel-b1-juan-reiser-pontificia-universidadcatolica-del-peru [Accessed 11 December 2016].

Rochlin, S., Bliss, R., Jordan, S., \& Kiser, C. Y. (2015). Defining the competitive and financial advantages of corporate responsibility and sustainability. Babson College: Project ROI Sponsors

Schneller, C., \& Thöni, E. (2011). Universities and their social responsibilities. 2nd Asia-Europe Education Workshop, Innsbruck, June, 5 - 7

Shawyun, T., Al-Kaarni, A., Al-Shehri, M., \& Al-Hamali, R. (2016). From CSR to USR: A strategic USR management framework. In N. Anderson (Ed.). Proceedings of the 7th QS-APPLE Conference Manila, 16th - 18th November, pp. 115-127.

The Council for Industry and Higher Education (2009). Ethics matters: Managing ethical issues in higher education. London: CIHE and Brunel University.

Toukabri, M., Ben Jemâa, O., \& Jilani, F. (2014). Corporate social disclosure: Explanatory theories and conceptual framework. International Journal of Academic Research in Management, 3(2), 208-225.

Turyakira, P., Venter, E., \& Smith, E. (2012). Corporate social responsibility for SMEs: A proposed hypothesised model. African Journal of Business Ethics, 6(2), 106-122.

Vest, C. M. (2006). Industry, philanthropy, and universities: the roles and influences of the private sector in higher education. Research and Occasional Paper Series: CSHE.12.06. Berkeley: University of California, Centre for Studies in Higher Education.

Weiss, B. (2016). The rise of social responsibility in higher education. University World News, No. 423. Available from: http://www.universityworldnews.com/article.php?story=2016081109580895 9 [Accessed 9 December 2016].

Wicks, A. C., Freeman, R. E., \& Parmar. B. (2004). Stakeholder theory and the corporate objective revisited. Organization Science, 15(3), 364-369. 